\title{
Type study of Calvatia lachnoderma from Brazil
}

\section{Cortez VG ${ }^{1,2^{*}}$ and Alves $\mathrm{CR}^{2}$}

\author{
${ }^{1}$ Universidade Federal do Paraná, Rua Pioneiro 2153, Jardim Dallas, Palotina, PR, Brazil \\ ${ }^{2}$ Universidade Federal do Paraná, Programa de Pós-graduação em Botânica, P.O. Box 19031, Curitiba, PR, Brazil
}

Cortez VG, Alves CR 2012 - Type study of Calvatia lachnoderma from Brazil. Mycosphere 3(5), 894-898, Doi 10.5943 /mycosphere/3/6/3

Calvatia lachnoderma was described by Patouillard in 1907 based on material collected by P.F. Noack, in the State of São Paulo, southeast Brazil. The species was not considered in accounts of gasteroid fungi from Brazil, nor in recent monographs on the genus. We examined type material from Farlow Herbarium and concluded that it is a good species in the genus, based mostly on peridium texture, basidiospore size/shape and ornamentation under scanning electron microscopy (SEM). The holotype is the only available material. A description of the microscopic features is provided, as well as SEM analysis of the basidiospores and brief taxonomic discussion.

Key words - Agaricomycetidae - gasteromycetes - puffball - taxonomy

\section{Article Information}

Received 9 October 2012

Accepted 10 October 2012

Published online 9 November 2012

*Corresponding author: Vagner Gularte Cortez - cortezvg@ yahoo.com.br

\section{Introduction}

In 1907, the French mycologist N.T. Patouillard described, among other fungal species, a puffball that he named Calvatia lachnoderma. The specimens were sent to him by P.F. Noack, who collected the type in the municipality of Araraquara, State of São Paulo, southeast region of Brazil. Since then, $C$. lachnoderma has, except for a recent checklist of the Brazilian gasteromycetes (TrierveilerPereira \& Baseia 2009) never received any mention in the Brazilian mycological literature, even in specific studies on the genus (Silveira 1943, Baseia 2003, Cortez et al. 2012). Even Kreisel (1989, 1992, 1994), in his world accounts of Calvatia s.l. did not mention this species, which remains unknown since its original description by Patouillard (1907).

In the course of a survey of the gasteroid fungi from the western region of Paraná State, in southern Brazil (Alves \&
Cortez 2013), we considered it relevant to study some of the species reported from the subtropical zone of Brazil, including the type material of $C$. lachnoderma. Thus, the holotype was requested in order to check its morphology, provide a modern description of microscopic data, including scanning electron microscopy (SEM) of the basidiospores, and verify the taxonomic status of the species it in the light of current generic concepts.

\section{Methods}

Specimens were borrowed from the Farlow Herbarium (FH) at Harvard University. A microscopic examination was performed with a Motic BA310 optical microscope and measurements taken from MotiCam camera and processed by software Motic Image Plus software. Scanning electron microscopy (SEM) was performed at the Center of Electron Microscopy (CME) of the Universidade 
Federal do Paraná (UFPR) following methods described by Alves \& Cortez (2013).

\section{Taxonomy}

Calvatia lachnoderma Pat., Ann. Mycol. 5, 366, 1907. Figs 1-6

Original diagnosis (after Patouillard, 1907): "Peridio subgloboso vel ovoideo, 3-6 $\mathrm{cm}$ diam., superne rotundato inferne conico, rigido, firmo, crasso, laevi, minute velutino, rufulo, frustulatim dehiscenti; basi sterili peridii tertium inferum occupante, compacta, dura, celluloso-fibrosa, albo-olivascenti; gleba pulverulenta, ochracea dein obscure rufoochracea; capillitio parum evoluto, ex hyphis brevibus, vix ramosis, rufo-ochraceis, $5 \mu$ crassis formato; sporis globosis rufidulis, laevibus vel vix rugulosis, ecaudatis, $6 \mu$ diam. Hab. ad terram."

Type study: Macroscopically, the material presented the following features: basidiomata subglobose with a rooting base, peridium dark brown, with a slightly velutinous texture, but without conspicuous spines, irregular dehiscence, gleba pulverulent and dark brown, subgleba fibrous to cellular and not compact, reaching about $1 / 3$ to $1 / 2$ of basidioma height. Basidiospores 5-6 $\mu \mathrm{m}$ diam. (excluding ornamentation), globose to broadly ovoid in profile, in a few cases broadly ellipsoid, with strong and dense echinate ornamentation, the spines are sharp and measure up to $1.0 \mu \mathrm{m}$ in length; under SEM, the basidiospores present a conical spiny to verrucose ornamentation more or less connected by a gross reticulation, also a short pedicel $(<1 \mu \mathrm{m}$ long) can be seen in some basidiospores, although it is mostly obscured among the spines. Basidia not seen. Eucapillitium 3-6 $\mu \mathrm{m}$ diam., yellowish, filamentous, with dichotomous branches and tapering tips, pores numerous and circular, <1 $\mu \mathrm{m}$ diam. Peridium composed by three distinct layers: 1) external layer, composed by sparse groups of elliptical to subglobose hyphae, 15$27 \times 12-15(-23) \mu \mathrm{m}$, pale yellowish brown, walls thickened (2-5 $\mu \mathrm{m}$ thick); 2) middle layer, $110-150 \mu \mathrm{m}$ thick, formed by radially arranged hyphae, 4-7(-9) $\mu \mathrm{m}$ diam., yellow to yellowish brown, with slightly thickened walls; 3) internal layer, pseudoparenchymatic, composed of hyaline, subglobose, thin-walled hyphae, 16-32(-43) $\mu \mathrm{m}$ diam. locality.

Distribution - known only from type

Material examined - Brazil, São Paulo State, municipality of Araraquara, "ad terram", Nov 1896, leg. F. Noack 836 (HUH 00301413).

Notes - In the protologue Patouillard (1907) compared his new species to $C$. hesperia Morgan, from the USA, from which it differs in the absence of a sterile base, greenish yellow gleba, the smooth to punctuate basidiospores and eucapillitium with slit-like pores (Kreisel 1989, Zeller \& Smith 1964). Calvatia hesperia, however, was considered in the genus Gastropila Homrich \& J.E. Wright by Ponce de León (1976) and later in Handkea Kreisel by Kreisel (1989); these data obviously suggest that it is a very distinct puffball.

The most interesting features of $C$. lachnoderma, as mentioned in the protologue, as well according to our own observations, are the following: smooth to minutely velutinous and dark brownish exoperidium, the fibrous to cellular subgleba and the size and ornamentation of the basidiospores.

The irregular dehiscence of the peridium, the medium-sized (about $1 / 3$ of basidioma height) and fibrous to cellular subgleba, the presence of eucapillitium with circular pores and the echinate basidiospores are features that support the placement in Calvatia s. str. (Calonge \& Martín 1990). In his notes, Patouillard (1907) mentioned "Scleroderma" on the herbarium sheet (Fig. 2); but it is not clear, what his intention was. On the basis of the above mentioned features, it cannot be considered a Scleroderma. Although the leathery peridium is suggestive of Gastropila, the echinate basidiospores and presence of a subgleba justify the placement in Calvatia.

Contrary to Patouillard's (1907) description of the basidiospores, reported as smooth to rugulose, his own notes and drawings (Fig. 2) show strongly ornamented basidiospores, as confirmed also in our own examination, both under light microscopy and SEM. Indeed, the distinct spiny ornamentation pattern could be observed under SEM, composed of densely grouped conical 


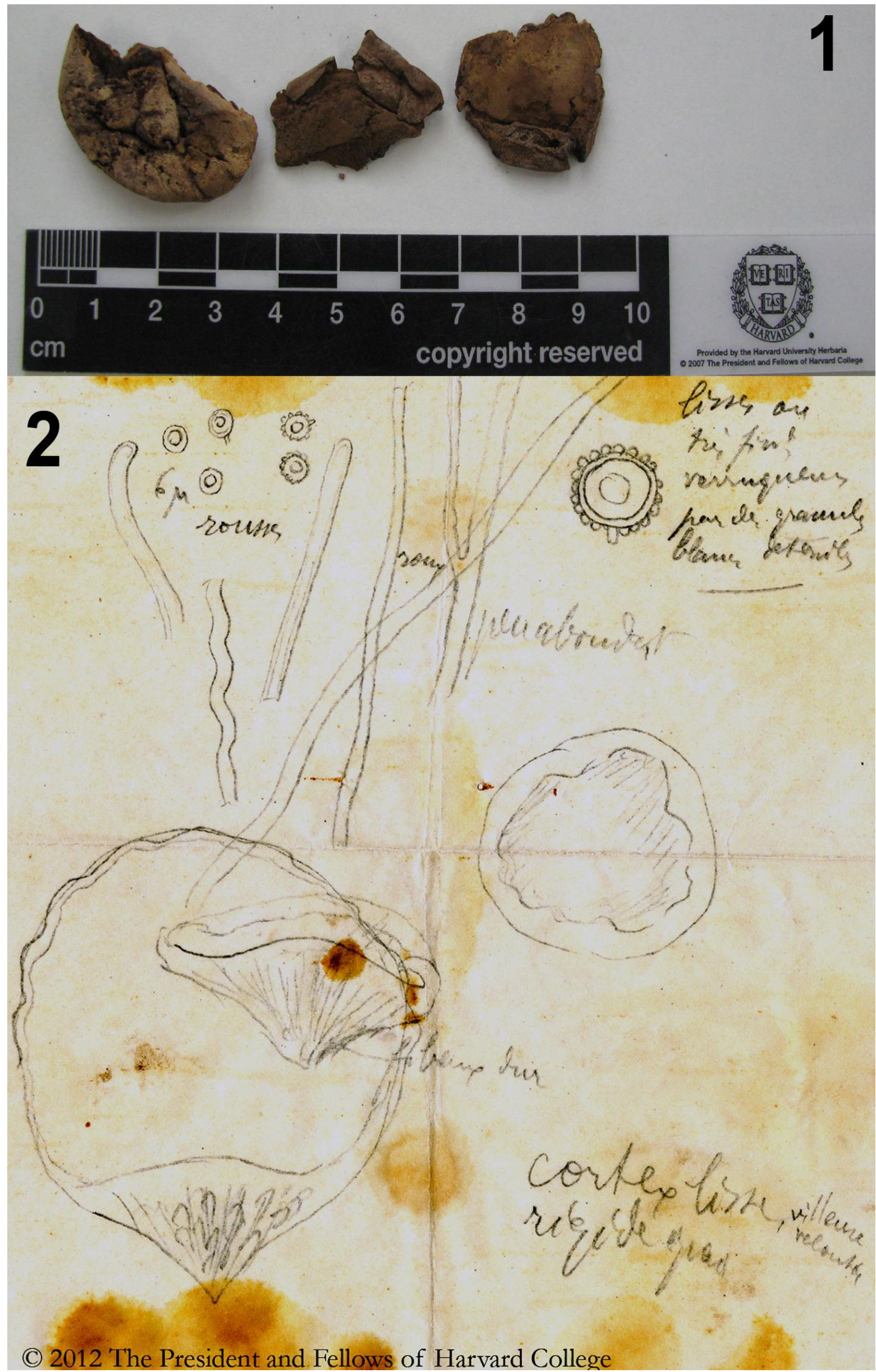

Figs 1-2 - Calvatia lachnoderma. 1 Type specimen. 2 Original notes accompanying the type. All images from Farlow Herbarium, Harvard University Herbaria, Harvard University, Cambridge, Massachusetts, USA. 


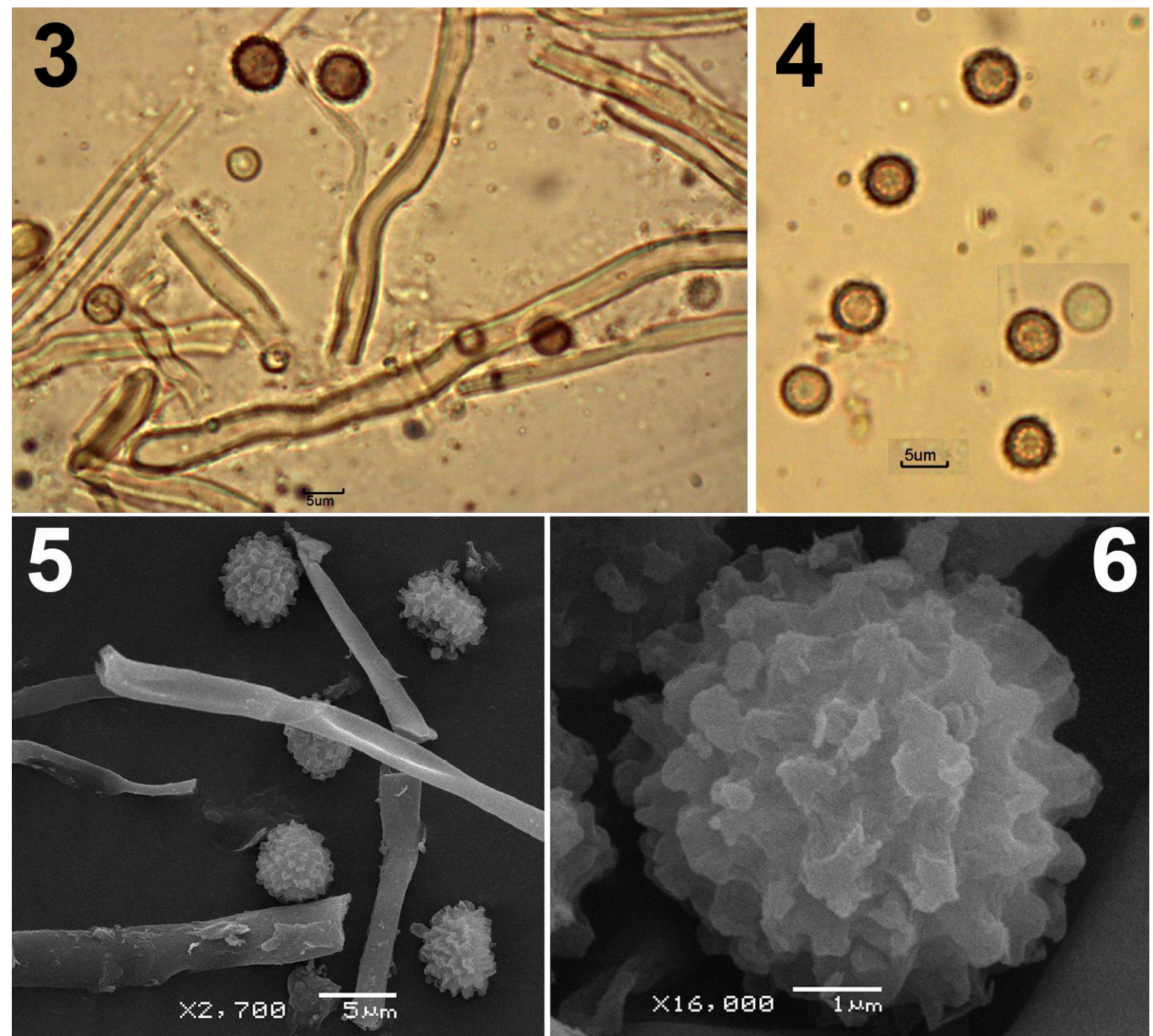

Figs 3-6 - Calvatia lachnoderma. 3 Basidiospores and eucapillitium. 4 Basidiospores. 5 Basidiospores and eucapillitium under SEM 6 Basidiospore under SEM. All images from holotype.

verrucae. The short pedicel is best seen under SEM, although it is usually obscured by the dense ornamentation, justifying Patouillard's description of basidiospores as "ecaudatis" (tailless, without pedicel).

Unfortunately, Patouillard (1907) did not furnish additional information on the habitat where the fungus was collected, except that it was growing on soil. It would be important to know at least if it was a forest or open area species, because it is known that these habitats harbour distinct taxa in the genus (Kreisel 1994, Coetzee \& van Wyk 2009, Cortez et al. 2012). It is hoped that the present contribution will encourage mycologists working in the subtropical zone of southeast and southern Brazil to be on the look-out for this poorly known species, thus improving knowledge on the Brazilian Calvatia.

\section{Acknowledgements}

We thank Michaela Schmull and Genevieve Lewis-Gentry (Farlow Herbarium, Harvard University Herbaria, Harvard University, Massachussets, USA) for providing images and loan of the holotype, CME/UFPR for facilities on performing SEM analysis, and CNPq (Proc. No 478373/2010-4) for financial support to this research and Johannes C. Coetzee (Cape Peninsula University of Technology, South Africa) for pre-submission review of the manuscript.

\section{References}

Alves CR, Cortez VG. 2013 - Morganella sulcatostoma sp. nov. (Agaricales, Basidiomycota) from Paraná State, Brazil. Nova Hedwigia, in press. 
Baseia IG. 2003. Contribution to the study of the genus Calvatia (Lycoperdaceae) in Brazil. Mycotaxon 88: 107-112.

Calonge FD, Martín MP. 1990 - Notes on the taxonomical delimitation in the genera Calvatia, Gastropila and Langermannia (Gasteromycetes). Boletín de la Sociedad Micológica de Madrid 14, 181-190.

Coetzee JC, van Wyk AE. 2009 - The genus Calvatia ('Gasteromycetes', Lycoperdaceae): a review of its ethnomycology and biotechnological potential. African Journal of Biotechnology 8, 6007-6015.

Cortez VG, Baseia IG, Silveira RMB. 2012 Gasteroid mycobiota of Rio Grande do Sul, Brazil: Calvatia, Gastropila and Langermania (Lycoperdaceae). Kew Bulletin 67, 471-482.

Kreisel H. 1989 - Studies in the Calvatia complex (Basidiomycetes). Nova Hedwigia 48, 281-296.
Kreisel H. 1992 - An emendation and preliminary survey of the genus Calvatia (Gasteromycetidae). Persoonia 14, 431439.

Kreisel H. 1994 - Studies in the Calvatia complex (Basidiomycetes) 2. Feddes Repertorium 105, 369-376.

Patouillard N. $1907 \quad-$ Basidiomycètes nouveaux du Brésil recueillis par $\mathrm{F}$. Noack. Annales Mycologici 5, 364-366.

Ponce de León P. 1976 - Notes on the genus Gastropila. Phytologia 33, 455-466.

Silveira VD. 1943 - O gênero Calvatia no Brasil. Rodriguésia 16, 63-80.

Trierveiler-Pereira L, Baseia IG. 2009 - A checklist of the Brazilian gasteroid fungi (Basidiomycota). Mycotaxon 108, 441444.

Zeller SM, Smith AH. 1964 - The genus Calvatia in North America. Lloydia 27, 148-186. 